удк 331.101

\title{
МЕТОДИ ТА СПОСОБИ ОЦІНЮВАННЯ КОМАНДНОЇ ЗАЛУЧЕНОСТІ
}

\section{METHODS AND WAYS OF ASSESSMENT OF TEAM ENGAGEMENT}

\author{
Винничук Роксолана Олександрівна \\ кандидат економічних наук, доцент, \\ Національний університет «Львівська політехніка» \\ ORCID: https://orcid.org/0000-0002-4727-395X \\ Любомудрова Надія Петрівна \\ кандидат економічних наук, доцент, \\ Національний університет «Львівська політехніка» \\ ORCID: https://orcid.org/0000-0002-1982-0442 \\ Довгополюк Ірина Михайлівна \\ студент, \\ Національний університет «Львівська політехніка» \\ ORCID: https://orcid.org/0000-0001-6978-0082
}

\section{Vynnychuk Roksolana, Lyubomudrova Nadiya, Dovhopoliuk Iryna \\ Lviv Polytechnic National University}

\begin{abstract}
Стаття передбачає дослідження основних методів та способів, які стосуються оцінювання командної залученості персоналу. Особливий акцент робиться на важливості фрормування та управління командною залученістю працівників організації. Визначено основні інструменти для моніторингу залученості персоналу організації, а також їх зміст, переваги і недоліки. Встановлено ключові вимоги до опитування персоналу та пояснено важливість кожної з вимог, а також визначено показники ефективності залученості працівників організації. Описано три послідовні етапи реалізування системи залученості персоналу організації, зокрема: планування заходів, проведення запланованих заходів з переліком конкретних кроків, та оцінка ефективності проведених заходів щодо покращення залученості персоналу організації.
\end{abstract}

Ключові слова: залученість, команда, управління персоналом, оцінювання залученості.

Статья предусматривает исследование основных методов и способов, которые касаются оценки командной вовлеченности персонала. Особый акцент делается на важности фрормирования и управления командной вовлеченностью работников организации. Определены основные инструменты для мониторинга вовлеченности персонала организации, а также их содержание, достоинства и недостатки. Установлено ключевые требования к опросу персонала и объяснено важность каждой из требований, а также определены показатели эффрективности вовлеченности работников организации. Описаны три последовательных этапа реализуемость системы вовлеченности персонала организации, в частности: планирование мероприятий, проведения запланированных мероприятий с указанием конкретных шагов, и оценка эфрфективности проведенных мероприятий по улучшению вовлеченности персонала организации.

Ключевые слова: вовлеченность, команда, управление персоналом, оценивание вовлеченности.

Today, personnel is the principal capital and core value of any enterprise. It is crucial not only the individual productivity of an individual employee but also his ability to work in a team. The article provides a study of different methods and ways to assess employees' engagement in terms of their interaction in the team. The engagemented employee is proactive, active, loyal to his company, productive and efficient, involved in change processes, as well as often an agent of change. The authors of the paper emphasize the importance of forming and managing team engagement of employees of the organization as a critical factor in the effectiveness of many management processes. The document lists the primary tools used to monitor the engagement of the organization's staff, including: "pulse" surveys, analysis of feelings, the net indicator of the employee's promoter, personal interview, and the last interview, which is conducted at the stage of dismissal. These tools are analyzed in terms of their content, as well as advan- 
tages and disadvantages are described. Critical requirements for personnel interviews were also formulated, including anonymity, confidentiality, feedback, regularity, socially desirable responses, ease of evaluation, and scope. The article's authors explained why compliance with these requirements in employee surveys on their engagement is essential and effective. Three main stages of implementation of the employee engagement system were identified. Within the first stage, which is to plan activities engagement personnel, the key performance indicators are identified, including employee loyalty, active and passive staff turnover, absenteeism, business profitability, customer satisfaction, training efficiency, and others. The second stage identifies the main steps for implementing the planned measures, and the third stage is to assess the effectiveness of these measures by conducting a re-survey. The article emphasizes that the engagement process should be part of the company's development strategy because it directly affects the results of its development.

Keywords: engagement, team, personnel management, engagement assessment.

Постановка проблеми. На сьогоднішній день персонал $є$ основним капіталом та основною цінністю будь-якого підприємства. Важливим $€$ не лише індивідуальна продуктивність праці окремого працівника, але й також здатність його до командної роботи. Організації зацікавлені створювати такі умови праці, при яких персонал максимально включений у всі бізнеспроцеси. Тому на перший план поряд 3 іншими поняттями виходить поняття залученості персоналу, яке ще досі трактується по-різному, але передбачає такі характеристики, як бажання працювати, відповідальність працівників за результати, любов до своєї роботи, готовність прийти на допомогу, синергія спільної роботи тощо. Залучений працівник $€$ ініціативним, активним, лояльним до своєї компанії, а також продуктивним та ефективним, включеним в процеси змін та часто сам є агентом змін. Якщо в організації корпоративна культура та середовище працюють на створення залученості персоналу - конкурентні позиції такої організації на ринку значно зростають. Проте важливими залишаються питання, як оцінити рівень залученості працівників; як зрозуміти чи ефективно вкладаються ресурси у цей процес; як визначити, які саме способи та методи є найкращими. Саме тому, тема дослідження $€$ актуальною та своєчасною.

Аналіз останніх досліджень і публікацій. Слід зазначити, що досліджувана тематика $\epsilon$ досить нова і достатньої наукової бази з цього питання ще немає. Згадки про залученість персоналу знаходимо в працях закордонних науковців Ф. Герцберга, У. Кана, Б. Шака, К. Воллард, Дж. Іона, Б. Равона, М. Гетенбі тощо. Серед українських вчених цим питанням займаються Н.М. Лисиця, Г.В. Бей, А.В. Василик, А.М. Гриненко. А конкретно проблематикою, яка стосується оцінювання рівня залученості, цікавляться Л.В. Щетініна, А.Є. Яструбинська, С. Рудакова, Н. Данилевич. також в цьому контексті варто згадати практичні дослідження компанії Делойт та
Інституту Геллапа, які безумовно дають розширену картину для розуміння процесів управління залученістю працівників у різних компаніях світу.

Виділення невирішених раніше частин загальної проблеми. Авторам статті видається доцільним структурувати саме процеси, які стосуються оцінювання рівня залученості працівників організації, виділивши ключові етапи фрормування системи управління залученістю персоналу.

Формулювання цілей статті. Основне завдання, яке ставлять перед собою автори статті полягає у аналізуванні інструментів для моніторингу залученості працівників організації, а також визначення основних заходів, необхідних для реалізації системи управління залученістю персоналу.

Виклад основного матеріалу. Всі люди мають вроджені якості, які дозволяють їм досягти успіху. Відповідність між цими сильними сторонами та завданнями або ролями може створити надзвичайні результати діяльності, а працівники, які діють, використовуючи свої сильні сторони, як правило, більш залучені, ніж інші. Узагальнення працівників розмиває ці відмінності. У керівників, які узагальнюють сильні сторони працівників, можуть виникати проблеми із використанням людського капіталу та залученістю.

Індивідуалізація дозволяє керівникам бачити унікальні якості працівників, а також виявляти потреби, які відрізняються від працівника до працівника. Менеджери повинні разом 3 учасниками команди визначати потреби та перешкоди на даний час та в перспективі і вживати заходів до того, як виклики почнуть гальмувати продуктивність працівників. Незважаючи на появу безлічі інструментів для вимірювання настроїв співробітників, більшість організацій продовжують вимірювати залученість раз на рік, що в сучасних умовах стрімкого та динамічного розвитку ринку $€$ недостатнім. Необхідно регулярно 
проводити аналіз і відслідковувати рівень залученості персоналу.

Моніторинг залученості відбувається у три етапи. Спершу необхідно визначити відповідні фактори залученості, які актуальні для тієї чи іншої компанії. Далі необхідно здійснити збір даних безпосередньо від працівників через різні канали. Зрештою, ці дані аналізуються на основі ключових показників, які кількісно оцінюють рівні взаємодії всієї організації.

Для вимірювання залучення працівників можуть бути використані інструменти та методології, що запропоновані у таблиці 1.

Як видно з таблиці 1, всі зазначені інструменти мають свої переваги та недоліки. Рішення щодо їх застосування - вибір кожної організації.

Найбільш поширеним, ефективним та доступним способом проведення моніторингу залученості персоналу, який може дозволити собі практично кожна організація, - $€$ опитування. Варто дотримуватися певних вимог до проведення такого опитування, які відображені в таблиці 2.

Ці вимоги $€$ інструктуючими та рекомендаційними. Опитування щодо залучення працівників $€$ корисним інструментом для вимірювання ставлення працівників до своєї роботи та рівня корпоративної культури компанії. Хоча вони не описують повну історію зайнятості працівників, вони можуть бути цінними в наданні співробітникам можливості, щоб висловити свої погляди та допомогти організації зрозуміти досвід працівників на роботі. При застосуванні, спільно 3 іншими корисними інструментами залучення персоналу, опитування можуть бути ефективним способом, який допомагає виміряти і покращити залучення працівників.

При формуванні опитувальника варто враховувати чинники залученості, які притаманні організації, в якій воно проводиться. Так американським інститутом Геллапа було розроблено 12 універсальних персоніфікованих запитань «Gallup's Q12 Employee Engagement Survey Questions» [6].

При якісному зворотному зв'язку відкрита та активна зустрічна поведінка менеджера будує робоче середовище, де працівники почуваються безпечно та хочуть експериментувати з новими ідеями, обмінюватися інформацією, досліджувати можливості для розвитку та підтримувати один одного у своїй роботі та особистому житті.

Незалежно від галузі, в якій функціонує організація, відомо, що зростання бізнесу має прямий зв'язок із залученість працівників. Справжня залученість працівників відіграє важливу роль для успіху бізнесу. Кожна компанія, організація $€$ особливою, і може змінюватися 3 року в рік, однак для відслідковування ситуації варто обрати кілька показників (KPI), які будуть орієнтирами, куди рухається компанія. Идеться не лише про створення та надсилання відкритих опитувань щодо залученості працівників, що, безумовно, може бути частиною загального проекту щодо залучення працівників, але і про ряд інших показників.

Система залучення персоналу реалізується за допомогою заходів, які можна об'єднати в три основні етапи:

Етап 1. Планування заходів. Керівники підприємства і представники відділу кадрів проводять опитування на визначення рівня залученості персоналу через індикатори, які цілком залежать від цілей організації і аналізують отримані результати. Ці індикатори подано у таблиці 3.

Необхідно підібрати саме ті індикатори, які $€$ актуальними для конкретної організації. Можна скористатися технікою «SMART», де критеріями вибору індикаторів буде їхня конкретність, вимірність, реалістичність та обмеженість у часі. Цінність КРІ полягає в можливості оцінки прогресу організації у досягненні стратегічних цілей. Цей спосіб використовується для вимірювання залучення працівників та встановлення цілей організації. КPI дають уявлення про стан справ при визначенні якісних та кількісних даних про залучення працівників, необхідних кожній організації, контакт $з$ працівниками. Слід зазначити, що без активного залучення співробітників до розроблення системи KPI, неможливо дізнатися, чи матимуть дослідження результат.

Далі потрібно для кожного підрозділу або групи працівників розробити відповідні заходи та обрати інструменти для підвищення цього показника. Процес залученості повинен стати частиною стратегії розвитку компанії, адже напряму впливає на результати їі розвитку. У компанії повинна бути сфрормована культура залученості, яка здійснює вплив на працівника вже з його першого робочого дня.

Етап 2. Реалізація заходів, передбачених планом. Для прикладу, можна дотримуватись таких кроків:

1) актуалізувати цінності компанії, вести їх активну пропаганду, сприяти тому, щоб робочий простір став їх відображенням;

2) окреслити шляхи кар'єрного росту та надати можливості для навчання; 
Таблиця 1

Інструменти для моніторингу залученості персоналу

\begin{tabular}{|c|c|c|c|}
\hline Інструмент & Зміст & Переваги & Недоліки \\
\hline $\begin{array}{l}\text { «Пульсові» } \\
\text { опитування }\end{array}$ & $\begin{array}{l}\text { Це швидка і часта система опитувань, } \\
\text { яка не ставить складних питань } \\
\text { і розрахована на щотижневе або } \\
\text { щомісячне опитування. Вона дає } \\
\text { швидке уявлення про стан «здоров'я» } \\
\text { компанії, звідси і назва «пульс». } \\
\text { Зараз фахівці рекомендують } \\
\text { припинити проводити щорічні } \\
\text { опитування та, замість цього, } \\
\text { проводити «обстеження пульсу». } \\
\text { Часті опитування дають уявлення } \\
\text { про стан залученості до організації. } \\
\text { Завдяки технологіям, «пульсові» } \\
\text { опитування можна проводити через } \\
\text { Інтернет. }\end{array}$ & $\begin{array}{l}\text { - Швидкість та } \\
\text { оперативність } \\
\text { отриманої інфоромації; } \\
\text { - показують } \\
\text { актуальний стан; } \\
\text { - «хмарне програмне } \\
\text { забезпечення»як } \\
\text { правило, постійно } \\
\text { вдосконалюється, } \\
\text { і у ньому можуть } \\
\text { з'являтися нові } \\
\text { корисні фрунції; } \\
\text { - можливість уникати } \\
\text { «запущених» } \\
\text { проблем. }\end{array}$ & $\begin{array}{l}\text { - можуть } \\
\text { бути занадто } \\
\text { частими; } \\
\text {-є ймовірність } \\
\text { не завжди } \\
\text { чесних } \\
\text { відповідей } \\
\text { персоналу. }\end{array}$ \\
\hline $\begin{array}{l}\text { Аналіз } \\
\text { почуттів }\end{array}$ & $\begin{array}{l}\text { Метод вилучення інорормації з } \\
\text { суб'єктивних даних, що виявляються } \\
\text { в мові, яку співробітники } \\
\text { використовують у своїх онлайн- } \\
\text { розмовах. Усі зібрані дані } \\
\text { зберігаються анонімними. Аналіз } \\
\text { почуттів може дати реальне уявлення } \\
\text { про те, чи чесно відповідають } \\
\text { працівники опитувань. }\end{array}$ & $\begin{array}{l}\text { - може допомогти } \\
\text { виявити загальні } \\
\text { настрої; } \\
\text { - комбінуючись через } \\
\text { дані електронної } \\
\text { пошти та чату, } \\
\text { інструменти аналізу } \\
\text { настроїв дозволяють } \\
\text { ідентифікувати } \\
\text { токсичну поведінку } \\
\text { на робочому місці в } \\
\text { командах. }\end{array}$ & $\begin{array}{l}\text { - може } \\
\text { прийнятись } \\
\text { працівниками } \\
\text { як втручання в } \\
\text { особисте. }\end{array}$ \\
\hline $\begin{array}{l}\text { Чистий } \\
\text { показник } \\
\text { промоутера } \\
\text { працівника } \\
\text { (eNPS) }\end{array}$ & $\begin{array}{l}\text { Employee Net Promoter Score - це } \\
\text { показник, який використовується для } \\
\text { вимірювання лояльності працівників. } \\
\text { Застосовується для уявлення про те, } \\
\text { як пропагують організацію як місце } \\
\text { роботи. Складається з 3-х питань. } \\
\text { щоб еNPS був дійсним показником } \\
\text { залучення працівників, він повинен: } \\
\text { - проводитись через рівні проміжки } \\
\text { часу - щомісяця або щокварталу. } \\
\text { - збирати анонімні відповіді. } \\
\text { - поєднуватись з даними, } \\
\text { отриманими в результаті опитувань } \\
\text { та інших джерел. }\end{array}$ & $\begin{array}{l}\text { - показує реальну } \\
\text { кількість лояльних } \\
\text { працівників, } \\
\text { нейтральних та } \\
\text { критиків. }\end{array}$ & \\
\hline $\begin{array}{l}\text { Особиста } \\
\text { бесіда }\end{array}$ & $\begin{array}{l}\text { Жодна технологія не може замінити } \\
\text { людський зустрічей. Працівники } \\
\text { відповідають на почуте, коли мають } \\
\text { можливість вести живу розмову, щоб } \\
\text { висловити думки. Анонімний відгук } \\
\text { може допомогти побачити глобальні } \\
\text { проблеми. Для конкретних особистих } \\
\text { питань щомісячні зустрічі один на } \\
\text { один - це відмінний спосіб для } \\
\text { керівників дізнатись, що насправді } \\
\text { думають працівники. }\end{array}$ & $\begin{array}{l}\text { - конкретизація } \\
\text { проблем; } \\
\text { - діалог; } \\
\text { - допомагає } \\
\text { працівнику працювати } \\
\text { з великою загальною } \\
\text { стратегією / } \\
\text { завданням; } \\
\text { - відчуття того, що } \\
\text { праця є помітною. }\end{array}$ & $\begin{array}{l}\text { - працівник } \\
\text { може бути } \\
\text { наляканим та } \\
\text { нещирим. }\end{array}$ \\
\hline $\begin{array}{l}\text { Останнє } \\
\text { інтерв'ю }\end{array}$ & $\begin{array}{l}\text { Цей метод застосовують для } \\
\text { опитування тих працівників, які вже } \\
\text { вирішили звільнитися з підприємства. } \\
\text { Знаючи, чому люди йдуть, можна } \\
\text { вжити ряд заходів щодо усунення } \\
\text { причин плинності кадрів. }\end{array}$ & $\begin{array}{l}\text { - за умови відвертості } \\
\text { працівника можна } \\
\text { отримати багато } \\
\text { цінної інорормації. }\end{array}$ & $\begin{array}{l}\text { - працівник } \\
\text { може бути } \\
\text { наляканим та } \\
\text { нещирим. }\end{array}$ \\
\hline
\end{tabular}


Таблиця 2

Вимоги до опитування персоналу

\begin{tabular}{|c|c|}
\hline Вимога & Чому це важливо \\
\hline Анонімність & $\begin{array}{l}\text { Працівники мають бути впевнені в тому, що керівництво компанії не } \\
\text { дізнається про те, хто і які відповіді дав на запитання. Тож, в анкеті не } \\
\text { повинні бути вимоги до зазначення назви посади. Звичайно можуть бути } \\
\text { запитання стосовно того, до якого структурного підрозділу належить } \\
\text { працівник, аби виявити де саме існує та чи інша проблема, і локально її } \\
\text { вирішувати. Водночас, важливою є умова, що в підрозділі більше } 15 \text { осіб. } \\
\text { Тільки так можливо отримати правдиві відповіді, а саме вони є метою } \\
\text { дослідження - виявлення проблемних сторін, а не для того, щоб хибно } \\
\text { запевнити себе, що все добре і ніяких заходів вживати не потрібно. }\end{array}$ \\
\hline Конфріденційність & $\begin{array}{l}\text { Багато кому відомо, що з розвитком сучасних ІТ-технологій можна легко } \\
\text { перевірити, з якого носія була відправлена та чи інша відповідь. Тож, для } \\
\text { тих, хто дбає про збереження своєї конфріденційності, необхідно надати } \\
\text { можливість проходити опитування в паперовому вигляді, розставивши } \\
\text { бокси для анкет в офрісі. Також бажано долучити до обробки результатів } \\
\text { незалежну аудиторську організацію, яка надасть керівництву організації } \\
\text { суто цифри з висновками. Таким чином, жоден із співробітників не } \\
\text { буде долучений до такого важливого процесу, як обробка відповідей } \\
\text { співробітникам компанії. }\end{array}$ \\
\hline Зворотній зв'язок & $\begin{array}{l}\text { Надзвичайно важливо презентувати результати дослідження } \\
\text { співробітникам. По-перше, це показує довіру з боку компанії, об'єднує } \\
\text { працівників, адже вони ознайомленні з ситуацією, почувають себе } \\
\text { причетними до справ компанії. По-друге, якщо не давати зворотній } \\
\text { зв'язок, люди не будуть розуміти навіщо вони взагалі витрачали свій час } \\
\text { на проходження опитування, і з часом просто перестануть брати участь } \\
\text { у ньому. Працівники мають бачити результат, бачити якісь зміни, якщо є } \\
\text { проблеми, розуміти, що їх думка важлива та враховується. }\end{array}$ \\
\hline Регулярність & $\begin{array}{l}\text { Проведене одноразове опитування не вирішить проблем, адже відсутня } \\
\text { база для порівняння. Організовуючи опитування регулярно, компанія } \\
\text { має можливість відслідковувати як змінюється ситуація, чи ефективними } \\
\text { виявилися методи, які вона застосувала для вирішення існуючих проблем. }\end{array}$ \\
\hline $\begin{array}{l}\text { Соціаль } \\
\text { бажані в }\end{array}$ & $\begin{array}{l}\text { Запропоновані варіанти відповідей не мають бути критичними (тільки } \\
\text { «так» або «ні»), а навпаки мають давати можливість відповісти } \\
\text { найдостовірніше. Добре підійде відсоткова шкала, за якою працівник } \\
\text { відповідає, на скільки відсотків він погоджується з твердженням, або } \\
\text { ж система відповідей: повністю не згоден/ скоріше не згоден/ скоріше } \\
\text { згоден /повністю згоден. Доречно використовувати відкриті питання. }\end{array}$ \\
\hline $\begin{array}{l}\text { Зручність } \\
\text { оцінювання } \\
\text { результатів }\end{array}$ & $\begin{array}{l}\text { Процес підрахунку результатів і їх групування має бути автоматизованим. } \\
\text { зручним є електронний варіант, але якщо в паперовому (а це є доречним } \\
\text { для підвищення рівня конфіденційності), то варто розробити таку систему, } \\
\text { аби комп'ютер міг її «зчитати» та обробити отриманні дані. }\end{array}$ \\
\hline Обсяг & $\begin{array}{l}\text { За допомогою проведеного опитування хочеться дізнатися якомога більше. } \\
\text { Але це не означає, що анкета має бути дуже об'ємна, адже мало хто } \\
\text { захоче витрачати багато часу на їі проходження, в результаті 'ї̈ пройдуть } \\
\text { половина співробітників, що не дасть можливості отримати об'єктивні дані. } \\
\text { Тож, анкета має бути максимально лаконічною і кожне питання має бути } \\
\text { продуманим. Проходження анкети не має займати більше 15-20 хв. }\end{array}$ \\
\hline
\end{tabular}

Джерело: сфрормовано на основі [5]

3) визнавати працівників, які роблять значний вклад своєю діяльністю;

4) сприяти прозорості на всіх рівнях, починаючи із управлінської ланки;

5) дозволяти і сприймати зворотній зв'язок;

6) моніторити рівень залученості, застосовуючи різні інструменти, та сприяти рівному розподілу обов'язків між працівниками;
7) управлінська ланка повинна бути прикладом для працівників;

8) бути реалістичним, відповідальним, гнучким [8].

Етап 3. Аналіз ефективності проведених заходів шляхом проведення повторного опитування.

В часі здійснення всіх заходів, які спрямовані на дослідження та підвищення рівня 
Таблиця 3

KPI залученості персоналу

\begin{tabular}{|c|c|c|c|}
\hline № & Показник & Що дозволяє з'ясувати & $\begin{array}{c}\text { Нормативне } \\
\text { значення }\end{array}$ \\
\hline 1 & \begin{tabular}{|l|} 
Рівень лояльності працівника (Чистий \\
показник промоутера працівника) \\
(eNPS) (\%) - визначається шляхом \\
обчислення різниці між відсотком \\
промоутерів та критиків. \\
\end{tabular} & $\begin{array}{l}\text { Визначає рівень лояльності } \\
\text { працівників, дає зрозуміти, наскільки } \\
\text { ймовірний працівник рекомендувати } \\
\text { свою організацію як місце роботи. }\end{array}$ & $\begin{array}{c}30 \% \\
\text { перевага } \\
\text { промоутерів }\end{array}$ \\
\hline 2 & $\begin{array}{l}\text { Активна і пасивна плинність } \\
\text { кадрів (\%) - відношення між } \\
\text { кількістю працівників, які залишили } \\
\text { місце праці(з різних причин) до } \\
\text { середньоспискової чисельності. } \\
\end{array}$ & $\begin{array}{l}\text { Надмірна плинність кадрів говорить } \\
\text { про проблеми всередині компанії, } \\
\text { які призводять до втрати прибутку } \\
\text { через часту зміну персоналу. }\end{array}$ & $5-7 \%$ \\
\hline 3 & $\begin{array}{l}\text { Прогули(\%)- відношення між } \\
\text { кількістю прогулів та загальною } \\
\text { кількістю робочих днів. }\end{array}$ & $\begin{array}{l}\text { Рівень відсутності пов'язаний } \\
\text { із незацікавленням працівників } \\
\text { у роботі. }\end{array}$ & $<2.8 \%$ \\
\hline 4 & Рентабельність бізнесу & $\begin{array}{l}\text { Низький показник говорить про } \\
\text { низьку залученість персоналу. }\end{array}$ & \\
\hline 5 & Рейтинг Glassdoor & $\begin{array}{l}\text { Це веб-сайт, на якому працівники } \\
\text { можуть залишати свої відгуки } \\
\text { про своїх роботодавців. Огляди } \\
\text { допомагають підприємствам } \\
\text { дізнатися, що думають їх нинішні } \\
\text { та попередні працівники про } \\
\text { організацію. }\end{array}$ & \\
\hline 6 & $\begin{array}{l}\text { Невдалий найм(New Hire } 3 \text { Months } \\
\text { Failure Rate) }\end{array}$ & $\begin{array}{l}\text { Якщо нові працівники залишають } \\
\text { компанію протяом перших } 90 \text { днів, } \\
\text { вони або є не задоволені політикою, } \\
\text { або процес найму був здійснений } \\
\text { неправильно. }\end{array}$ & \\
\hline 7 & $\begin{array}{l}\text { Рівень задоволеності клієнтів (NPS) } \\
\text { (\%) - різниця між задоволеними та } \\
\text { незадоволеними клієнтами. }\end{array}$ & \begin{tabular}{|l|} 
Якщо рівень NPS клієнтів низький, \\
то ступінь залученості співробітників \\
низькою та є причиною \\
незадоволеності клієнтів.
\end{tabular} & \\
\hline 8 & $\begin{array}{l}\text { Показник внутрішнього кар'єрного } \\
\text { зростання (\%) - відношення } \\
\text { кількості ключових позицій в } \\
\text { компанії, яке зайняли свої ж } \\
\text { працівники «виросли», до загальної } \\
\text { кількості ключових позицій. } \\
\end{array}$ & $\begin{array}{l}\text { Внутрішні підвищення дозволяють } \\
\text { співробітнику швидше освоїтися } \\
\text { на новому місці, знижують } \\
\text { ризик невдалого найму, а самі } \\
\text { співробітники довше залишаються } \\
\text { в компанії. } \\
\end{array}$ & \\
\hline 9 & Ефрективність навчання & $\begin{array}{l}\text { Навчання ефективне тоді, коли воно } \\
\text { досягає поставлених цілей. }\end{array}$ & \\
\hline 10 & $\begin{array}{l}\text { Рівень задоволення працівників (\%) - } \\
\text { питання оцінюється від } 1 \text { до } 10 \text { балів і } \\
\text { ділиться на } 3 \text { помножене на } 100 .\end{array}$ & $\begin{array}{l}\text { Дає змогу дізнатись ставлення } \\
\text { до того чи іншого питання. }\end{array}$ & від 0 до 100 \\
\hline
\end{tabular}

Джерело: сфрормовано на основі [7]

залученості, необхідно вести постійну змістовну комунікацію, для того, щоб максимально інформувати своїх працівників про те, що саме і з якою метою відбувається.

Висновки. Таким чином, аналіз інструментів моніторингу залученості персоналу дає можливість виокремити важливі показники, якими можна виміряти рівень залученості та лояльності працівника. Визначивши переваги та недоліки кожного інструменту бачимо, що переваги безумовно переважають, а отже такі інструменти справді доцільно використовувати для оцінювання залученості персоналу. Перелік вимог до опитування персоналу допомагає чітко проводити збір інорормації щодо залученості працівників та витрачати значно менше ресурсів на цей процес. Оцінювання кроків кожного з етапів фрормування системи управління залученістю працівників, в тому числі й командною залученістю, пока- 
зав, що залученість персоналу - надзвичайно важливий показник, відслідковування й оцінювання якого має бути чітким та планомірним процесом. Особливу увагу варто звертати на ключові показники ефективності, які прямо чи опосередковано стосуються залученості працівників і які дають змогу оцінити такі важливі речі як: рівень лояльності працівника, активну та пасивну плинність кадрів, рентабельність підприємства, прогули та невдалий найм, рівень задоволеності клієнтів, показник вну- трішнього кар'єрного зростання, ефективність навчання та рівень задоволеності працівників. Організації повинні звертати увагу на описані у статті показники для кращого розуміння ефективності роботи системи управління персоналом загалом. В подальших дослідженнях цієї тематики доцільно, на нашу думку, зосередитися на процесах фрормування корпоративної культури залученості персоналу, а також на визначені шкали допустимих норм показників залученості.

\section{СПИСОК ВИКОРИСТАНИХ ДЖЕРЕЛ:}

1. Kahn William A. Psychological Conditions of Personal Engagement and Disengagement at Work. Academy of Management Journal. 1990. № 33(4). P. 692-724.

2. Shuck Brad, Wollard Karen K. Antecedents to Employee Engagement: A Structured Review of the Literature". Advances in Developing Human Resources. 2011. № 13(4). P. 429-446.

3. The Difference Between Happy Employees and Engaged Employees. URL: http://blog.rewardian.com/ employee-happiness-vs-employee-engagement-six-ways-to-promote-both

4. Employee Pulse Surveys. URL: https://inside.6q.io/everything-you-need-to-know-about-employee-pulse-surveys

5. Щетініна Л.В., Яструбинська А.Є. Оцінювання залученості персоналу: значення, вимоги та практичні рекомендації. Соціально-трудові відносини: теорія та практика. 2017. Випуск 2(14). С. 262-264.

6. Engagement Survey Questions. URL: https://www.gallup.com/workplace/285674/improve-employeeengagement-workplace.aspx

7. Employee Engagement KPl's. URL: https://www.opensourcedworkplace.com/news/52-employeeengagement-kpi-s

8. Employee Engagement Strategies That Actually Work. URL: https://builtin.com/employee-engagement/ employee-engagement-strategies

\section{REFERENCES:}

1. Kahn, William A. (1990) Psychological Conditions of Personal Engagement and Disengagement at Work. Academy of Management Journal, no. 33(4), pp. 692-724.

2. Shuck Brad, Wollard Karen K. (2011) Antecedents to Employee Engagement: A Structured Review of the Literature. Advances in Developing Human Resources, no. 13(4), pp. 429-446.

3. The Difference Between Happy Employees and Engaged Employees. Available at: http://blog.rewardian.com/ employee-happiness-vs-employee-engagement-six-ways-to-promote-both

4. Employee Pulse Surveys. Available at: https://inside.6q.io/everything-you-need-to-know-about-employeepulse-surveys

5. Shchetinina L.V., Yastrubynska A.Ye. (2017) Otsiniuvannia zaluchenosti personal: znachennia, vymohy ta praktychni rekomendacii. [Assessing personnel engagement: values, requrements and practical recommendations]. Sotsialno-trudovi vidnosyny: teoriia ta practyka, no. 2(14), pp. 262-264.

6. Engagement Survey Questions. Available at: https://www.gallup.com/workplace/285674/improve-employee-engagement-workplace.aspx

7. Employee Engagement KPl's. Available at: https://www.opensourcedworkplace.com/news/52-employeeengagement-kpi-s

8. Employee Engagement Strategies That Actually Work. Available at: https://builtin.com/employeeengagement/employee-engagement-strategies 